\title{
The Sustainability of Muslim Women Entrepreneurs: A Case Study in Malaysia
}

\author{
Endi Rekarti ${ }^{1}$, Zakaria Bahari ${ }^{2}$, Normaisarah M. Zahari ${ }^{3}$, Caturida Meiwanto Doktoralina ${ }^{1} \&$ Nor Asariah Ilias $^{3}$ \\ ${ }^{1}$ Fakultas Ekonomi \& Bisnis, Universitas Mercu Buana, Jakarta, Indonesia \\ ${ }^{2}$ Centre For Islamic Development Management Studies (ISDEV) Universiti Sains Malaysia, Pulau Pinang, Malaysia \\ ${ }^{3}$ School of Social Sciences Universiti Sains Malaysia, Pulau Pinang, Malaysia \\ Correspondence: Zakaria Bahari, Centre For Islamic Development Management Studies (ISDEV) Universiti Sains \\ Malaysia, Pulau Pinang, Malaysia.
}

Received: April 30, 2019

Accepted: May 30, 2019

Online Published: June 11, 2019

doi:10.5430/ijfr.v10n5p430

URL: https://doi.org/10.5430/ijfr.v10n5p430

\begin{abstract}
The number of women who engage in small entrepreneurs (SMEs) in Malaysia, Kelantan has a high number of Muslim businesswomen whose efforts have been in place for over ten years and their businesses are able to increase family income on sustainable. This paper aims to identify the types of sustainability activities undertaken by Muslim small business women in Kelantan and to analyse the factors that influence the viability of Muslim women entrepreneurs doing business there. A case study was conducted to answer the question of how Muslim women entrepreneurs can be sustainable in business. Interview respondents were selected from a random sampling conducted on 15 Muslim women entrepreneurs in Kelantan. These findings indicate the dry food product business is more sustainable than wet goods because the sale of dry goods is always in demand and does not require much initial capital. This study shows that the factors that influence the survival of Muslim women small entrepreneurs in Kelantan are divided into three categories i.e., First financial capital, the human capital of an inherited business and the family experience gained in the field plays a role. Last, the patient's spiritual element, which is deliberate and honest.
\end{abstract}

Keywords: entrepreneurs, sustainability, small business, Muslim women

\section{Introduction}

Islam encourages its people to do business to enhance their social and economic life, and nine out of ten sources of livelihood come from industry and entrepreneurship. Commerce is an excellent part of worship as is affirmed by Allah SWT in the Sura An-Nisa (4:29) of the Al-Quran. The market also allows worship to fulfil the demands of the legal status of such activity in Islam that must be carried out, but if another Muslim has done it, then this obligation must be carried out (fardu kifayah) for Muslims ( Segun, 2016; Hadi \& Zainol, 2015; Mamat, Nawang, \& Ramli, 2009).

Most entrepreneurs in developing countries face a lot in improving the working capital needed (Brush, De Bruin, \& Welter, 2009; Rekarti, Doktoralina, \& Srianah, 2017). In the current economic field, women are also reluctant to dedicate to contributing to enliven the area of entrepreneurship in Malaysia, but the rapid development of the country's economy has pushed many women to engage in entrepreneurship actively. According to Drucker, (2014), many women entrepreneurs have already succeeded and become famous millionaires, some of them more aggressive than men regarding their thoughts, feelings and actions. In the business world, women have a distinct competitive advantage compared to men. Most women are more willing to deal with the diversity of customers and are strong in fostering business activities (Idris \& Shahadan, 1991).

The involvement of women in business is increasing, and women who can venture into business need to have a strong spirit to survive the next test. According to Orhan \& Scott (2001), as much as $26 \%$ of traders in France are women, while women found 30\% of world businesses that appear annually. Additionally, Lee (1996) stated that $80.3 \%$ of Singapore's businesspeople are women compared to men at only $65.6 \%$.

Kelantan is a state within Malaysia which has a large market called the Pasar Besar Siti Khadijah (PBSK). The majority of traders there are Muslim women small business entrepreneurs who have long been engaged in business 
activities and are sustainable in their respective businesses. There are various types of businesses carried out by these women with raw materials such as fish, chicken, meat, vegetables and so on; textiles such as shirts, batik fabrics and so on as well as dry food such as serunding and traditional food of the Kelantan people namely laksam, laksa fat and so on. The existence of entrepreneurship can play an essential role in a country (Nugroho \& Sihite, 2015; Shahbaz, et.al 2013; Zahra, S. A., \& George, 2002).

Besides, sustainability is the ability to weather something in the long run. It refers to the same granting of value to future and present decision making (O. Omar, 2010). Lindgren and Packendorff (2003) looked at entrepreneurship as a good practise in their project by pointing out that entrepreneurship needs to be examined from the aspect of the interim action. The entrepreneurial action involves the future of individuals that will affect the social interactions between individuals and those involved in interdisciplinary related network efforts. Sustainability is diverse and generally across multiple fields (O. Omar, 2010; Kamaruddin \& Samsudin, 2014; Kamyab, 2014; Adewale, 2016; Ametorwo, 2016; Obi \& Okekeokosisi, 2018; Essayyad, Palamuleni \& Satyal, 2018; Gunawardana, Tantrigoda \& Kumara, 2018 ; Bachev, 2018).

Therefore, this study will reveal the factors that influence the sustainability of Muslim women entrepreneurs in Kelantan, Malaysia who have been trading more than ten years. Their business is only able to increase family income but not become a profitable career. Nevertheless, their businesses remain solid enough that they can last a longtime in the market.

\section{Conceptual Framework of the Study}

\subsection{Business Types That Contribute Sustainability to Muslim Women}

The market is one of the places for women to find cash income. The mastery of women in business is a common phenomenon in either urban or rural areas. According to a study by Normaisarah (2014), the sustainability of the entrepreneur is from the form of business being undertaken. Entrepreneurs in small businesses are more sustainable as most of them have been in business for more than three years. Their business is seen to be stable even though at some point they have to suffer losses if there is a disaster. This statement is supported by Megginson, Byrd, and Megginson (2000) who describe entrepreneurs doing small business as a situation that is more stable than other big companies. Cole \& Wolken, (1995); Scarborough, (2016); Wiklund \& Shepherd, (2005) stated that small businesses require only small capital. Therefore, most small entrepreneurs in this field are more successful and sustainable than entrepreneurs from the manufacturing sector and so on.

The PBSK is a significant market for such women. Because of the various types of businesses carried out at the PBSK, researchers have identified a genuinely sustainable entrepreneur in their business comprised of Muslim women entrepreneurs who sell dry goods (dried chilies, onions, shallot, garlic, ginger, lime and other type of kitchen needed etc.) and dry food (meat floss, fish crackers, dodol, sweets, Kelantan traditional cakes and other types of fast food). These entrepreneurs are chosen because many of them run their own business without hiring other employees to care for their stores. Many of them started trading more than ten years ago and inherited the business from their family. The Women Muslim entrepreneur of various ages ranging from 12 years to 70 years.

Therefore, it is undeniable that many of these respondents have been selling at the PBSK for about 30 years by selling only dry food. They stated that this venture required a small capital, and its products can be taken there in large quantities. Therefore, to give an overview of this research, our conceptual framework of the study is presented in Figure 1.

\subsection{Factors That Contribute to Muslim Women's Entrepreneurship}

Several factors influence Muslim women who are small entrepreneurs in Kelantan to do business like increasing household income, life-threatening factors, having business support from their families (especially husbands), maintaining broad business interests, doing business with sincere intention and always praying as one of their measures of faith. The factors consist of three specific elements that will be discussed further below, namely financial capital, human capital and spiritual capital. 


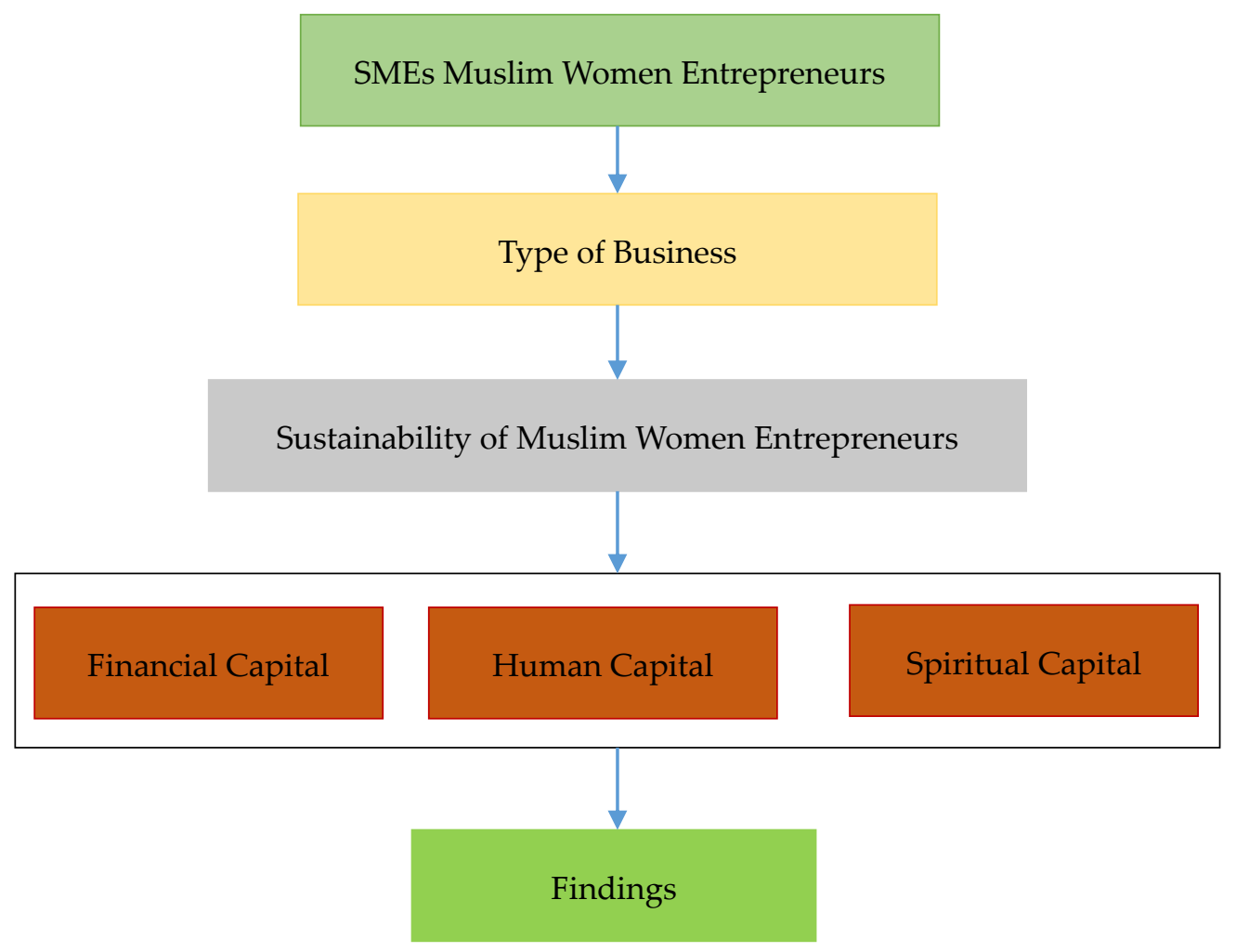

Figure 1. Conceptual framework of the study

\subsubsection{Financial Capital.}

Two financial factors motivate small businesswomen in Kelantan to conduct business activities. These factors are likely to increase household income and take over the husband's duties when the husband is carrying on other economic activities (Nor Aini \& Faridah, 1991). The first financial factor that drives them is to increase household income. Based on the marital status of Muslim women who are small entrepreneurs in Kelantan, 79\% of married couples agree that the existence of their business is because they want to increase household income, while another $21 \%$ stated other reasons. Of single entrepreneurial minority women, $60 \%$ agree, and $85 \%$ of those with a widow status also agree. The rest of the respondents gave other reasons for doing business. Many women entrepreneurs admit that, even though they are merely business-loving and seeking to earn more, when they start trading they begin to make the business a permanent career.

A private work entitled Entrepreneurs in Malaysia Ming-Yen \& Siong-Choy, (2007) explained the second factor of these businesses is to take over the husband's duties when he does other work. On the East Coast of the peninsula, history shows that women have long been in business, beginning with exchange activities under the barter system until the time of the use of money. The involvement of women is small-scale and merely taking a husband's duty. Therefore, women's focus is on the market. Goods traded are agricultural and fishery products initially issued for their use. When there is more production and the need to get other items grows, the results start to be marketed.

\subsubsection{Human Capital}

Three factors motivate small Muslim women entrepreneurs in Kelantan to trade between them because of the moral support of their husbands and families who encourage them to do business. Next is due to the broad interests of the business and the impetus of life that makes Muslim women entrepreneurs in Kelantan more likely to trade. According to Nor Aini and Faridah (1991), Muslim women who are small entrepreneurs are based on their marital status, with $10 \%$ of married women traders saying they are doing business for support and encouragement from husbands and families. When Muslim women entrepreneurs are favoured by their husbands to trade, as a wife this is important because of the redeeming of Allah SWT when her husband is pleased with everything that is done. So, this 
is a ritual for women in doing business because they can help their husbands in seeking a living. Support from this husband can be seen when female entrepreneurs are doing business in the market or are assured, and the husband is still coming to accompany his wife when he has time. There are also those who receive their small business capital from a husband's job, and this shows a husband's support for entrepreneurial women to jump into business.

De Vita, Mari, \& Poggesi, (2014) noted the factors that influence Muslim women who are small entrepreneurs to tend to trade are because of their interest in a business. Some Muslim women entrepreneurs who engage in activity have been involved with other work in the past, such as participating in wage-earning in the public and private sectors. There are also those who have worked alone but not in business. However, they now feel free and were dissatisfied concerning income when working under the direction of others. However, they are motivated to run their own business. This is supported by Lope and Elias (2004) who stated that the future of entrepreneurial women has a good outlook. So, the interest in becoming an entrepreneur makes them frustrated with other available work that will be carried out under someone else.

Amran Daud, (2004); Courtney, Łukowska, \& Williams, (2011); S. S. Omar, (2015) also has stated that the life-insistence factor caused the small Muslim women's entrepreneur to do business. Due to the absence of an education that is inconsistent with the requirements of the current field of employment, then at the insistence of life and family and friends, an individual begins trading whether small or large depending on the capital, ability, experience and support of people around. Their range of businesses includes groceries, beauty salons, laundry and other trades. This is acknowledged by De Vries, (1977) who expressed that the hardships and insistence of life encountered by every entrepreneur leads them to succeed in entrepreneurship.

\subsubsection{Spiritual Capital}

Spiritualism (like religion) is the inner or spiritual nature and soul that does not involve physical properties. For Muslim individuals who venture into business, it is essential to know that Islam is highly regarded as work, especially in business. If the business is done with the intentions and the lawful way, then the market is not only judged from the profit made but will also get the reward from Allah SWT. This is inline with the statement of (Asyraf, 2005; Singh, Simpson, Mordi, \& Okafor, 2011; Yaacob \& Azmi, 2012) that Muslim traders must be knowledgeable on all matters of the world and hereafter so that Allah SWT is pleased with the business.

The business practises followed by Muslim women who are small entrepreneurs are always done with the strong establishment (istiqamah) such as sincere intention and saying a prayer (shalat). A sincere intention is a practise that must be in every individual as every act to be done must be initiated with the intent. The intention is sincere because Allah SWT will remind the traders that Allah SWT is continuously monitoring the work, and that the sustenance obtained is used to the path of God Almighty. Besides, based on the hadith of the Prophet Mohammed by Imam Tirmidhi (No. 2616), Imam Ibn Majah (No. 3973) and Imam Ahmad (5/231 and 237), Muslims should not forget the shalat is a mandatory practise for every human being (Asyraf, 2005). Muslim women who are small businesspeople in Kelantan are very concerned about prayers because they are indeed educated always to pray and say a prayer for help from Allah SWT (Jermsittiparsert, Sriyakul \& Rodoonsong, 2013; Setiyawati, Iskandar \& Basar 2018). Considering such an environment as the market, its neighbourhood has mosques available for the Muslims to pray.

Thus, in examining the factors affecting the survival of Muslim women who are small entrepreneurs in Kelantan (as shown in Figure 1), they can determine the victory of these businesswomen and foster the three factors detailed above that influence the survival of Muslim small-scale entrepreneurs in Kelantan.

\section{Method}

This research used the qualitative approach with a case study method, and Muslim women entrepreneurs in Kelantan were the focus. Kelantan was chosen among the states in Malaysia because the majority of women entrepreneurs are Muslims. The participants have currently sustained their businesses for more than ten years in a row. The qualitative approach was chosen for this study due to the need to explore sequences and explain the phenomenon of theoretical development (Wye \& Lim, 2014; Iyiola, 2014; Maldonado-Guzman, et.al. 2018; Agbim \& Eluka, 2018; Udanoh \& Zouria, 2018; Okafor \& Shaibu, 2016; Bugu \& Yucheng, 2018).

Data collection was conducted through interviews with Muslim women entrepreneurs in Kelantan who were already doing sustainable business. The interview format was chosen because interviewers could provide essential information on the subject of study. All interviews were recorded (audio files), and then the audio was transcribed into text. Finally, all the data collected will be analysed along with secondary data from other written resources. 


\section{Findings and Discussion}

\subsection{Factors That Contribute to the Sustainability of Muslim Women}

Muslim women small entrepreneurs at the PBSK in Kelantan have been in business for more than ten years in the baked goods business. The selected business form is based on observations and interviews, for example, entrepreneurs of dry food. However, the real journey of these businesses is influenced by several factors: financial, human and spiritual (Normaisarah, 2014).

\subsubsection{Financial Capital}

Material factors can be defined as a matter that individuals need to continue their survival. Several material factors identified in influencing the sustainability of small entrepreneurs are to sell dry goods and food. The material factors sustainability of small Muslim women entrepreneurs are like the use of the owner's capital savings and carry out additional capital from saving group activities with other entrepreneurs.

\subsubsection{Owner's Capital Savings}

Every effort requires capital. After conducting interviews with Muslim women small entrepreneurs at the PBSK who operate food and dry goods businesses, most of these women started with initial money from their savings to make start-up capital or as start-up capital to get new stocks (Normaisarah, 2014). Lee-Gosselin and Grisé (1990), as well as Bruderl and Schussler (1990) also stated that women prefer to use business capital rather than their savings. Most of them started trading in small quantities. That means that when new to business, they sell only a few types of dry food like meat and fish crackers before they multiply their inventory. These women are smart in organising business strategies. As long as there is no debt, then this is to their advantage in doing business (Ahmed, Khalid, Ammar \& Shah, 2017). As such, this is one of the factors influencing the sustainability of Muslim women small entrepreneurs in Kelantan.

\subsubsection{Additional Capital From a Savings Group}

Additional capital from a savings group conducted by small entrepreneurs is usually conceptual in saving money in a congregation in fellow business owners. This format is small-scale and works by gaining trust with each other. The money earned comes from the savings group at a point in the future. They are more likely to carry out this activity, so when it comes to their turn, they can reuse the money as capital to buy goods and food for their business sales. These advance payments from the Islamic point of view are seen as interest-free loans by group members. For that reason in every month, all members of the group will donate to the loan that is to be returned within the stipulated time. This savings activity is also known as chit funds. Reda, (2013); Shannahan, (2016) stated that to maintain that the capital group is lawfully run, credible, recognised and agreed upon by Memorandum of Understanding (aqad) for the benefit of all benefits to avoid fraud and corruption (gharar). In conclusion, this additional capital from group saving between a limited partner and reasonable trustworthy colleagues and a written contract should be done since it is merely a borrowing activity and does not involve benefits for the future.

\subsection{Human Capital}

Human capital is the development of human resources for individuals, not only through knowledge, but by covering all aspects of personalities such as having a competent and robust identity as well as being capable of thinking creatively and critically. Competitive individuals need to have the skills to solve the problems faced and to have the ability to cope with the changing global environment of today.

\subsubsection{Family Heritage}

The results of the study conducted in Kelantan with Muslim women who are small entrepreneurs show that many of them are trading from a hereditary ancestral family business as did their grandmother and mother. Small business entrepreneurs with little capital provide many job opportunities to their family members (Kuratko \& Hodgetts, 2001; Megginson et al., 2000). To preserve their business, family members prefer to have their children inherit their activities to ensure that the efforts made so far are still working (Normaisarah, 2014). Therefore, the factors that affect the survival of these small Muslim women entrepreneurs are because they inherit the family trade. Thus, as business successors, they do not need to spend capital because the inherited trade has stabilised, and they are perpetuating the business by following the rules set by the government. They believe that if the family handles the trade, then the company can last forever. However, these women entrepreneurs continue to have challenges entrenched in trading diligently to perpetuate their accomplishments in striving to maximise profits so that their businesses do not suffer losses. 


\subsubsection{Experience}

Most of the Muslim women who are small entrepreneurs in Kelantan have commercial experience since adolescence. They started at the market during their teenage years as they accompanied their mother to trade there. At the same time, they could learn how to sell and manage their own business, so it cannot be denied that they become trained and educated in trading since childhood. Although they do not have a college education, they have valuable experience that has been nurtured since childhood, and they can sell their own freelance experience that teaches them to continue building their heritage business (Rekarti \& Doktoralina, 2017). Sitterly (1994) expressed the impression of expertise when children encourage them to become more independent in running the trade. Based on this, experience is a factor of sustainability.

\subsection{Spiritual Capital}

The spiritual factor can make a person quite human when it is applied in Islam, which mentions bodies, i.e. physical and mental health, i.e. a business called worship when executed following the Islamic Shari'a (Makhbul \& Hasun, 2010; Tlaiss, 2015). The spiritual factors that influence the sustainability of Muslim women in the PBSK are as follows:

\subsubsection{Patience}

Patience is required in Islam and needs to be in every human being. The value of a person's patience is high and also the achievement of one's glory. High patience needs to be present in every Muslim women who is a small entrepreneur to ensure their sustainability in the PBSK. In the commercial process, the time taken to determine the stage of profit takes a long time. According to Wan Sabri (2003) and Ramadani, Dana, Ratten, \& Tahiri, (2015), an entrepreneur triumph is a businessperson who has a store of patience to face difficulty and exhaustion and needs to try as though not facing any problem. Patience plays an essential role in determining their resilience in trade even if their business is not always profitable.

\subsubsection{Intentions}

The intention is the main thing that must be in every entrepreneur before doing something. Purposes will be seen on the behaviour and actions of individuals to become a spiritual value within themselves. All Muslim women entrepreneurs at the PBSK agree that intent is the most critical aspect of starting a business, and with a sincere intention and under the Islamic Shari'a they can last long at the PBSK. Muslim women who are small entrepreneurs in Shari'a are sure to choose the lawful business according to the Shari'a for their business. The halal guarantee requirement in pursuing this business is supported by (Arham, 2010; Zulkifli, Omar, Siti, \& Saripuddin, 2015) who noted entrepreneurs must carry on their business by Islamic law and aim to get the pleasure of Allah SWT(Ali \& Haseeb, 2019). They say, even though their company does not make a considerable profit, as long as their market is halal or inline with their intentions to support the family from the business outcome.

\subsubsection{Honesty}

Honesty is a spiritual value that also affects the preservation of Muslim women entrepreneurs at the PBSK. Stores are organised to be close together with each other. Interviews can show honest attitudes with almost all Muslim women entrepreneurs who admitted they are honest and trustful in their business. As an example, when a side shop does not have a seller because the seller goes on a break, they are permanent neighbours who will sell goods in the side shop if there are customers who want the goods. They have never been envious of the profits because each of them carries the same goods at almost the same with the same price. They believe that Allah's provision has been set beforehand. The exact attitude in keeping others' trust is due to the high awareness at the PBSK about family relationships and neighbourhoods nurtured in the past. They will not oppress each other because they trust each other.

\subsubsection{Charity}

Alms are a religious property (Abdullah S. and Mikail S A, 2013). As a result of the interviews with Muslim women, small entrepreneurs say they always give charitably from the results of their business. Although the amount is not much, they still give to the less fortunate. The alms produced from some of the sustenance gained is a rewarded practise multiplied by Allah SWT as described in the Quran Surah Al-Baqarah, (2: 261 \& 2:262) In other words, alms issued because the command of Allah SWT will bring more abundance to the people who always practise it. The alms should be sincere and not expected as a reward. Every act of charity should be hidden from the knowledge of the people and not spread around. This is what makes a charity as their practise and proves the spiritual power of the Muslim women entrepreneurs in the PBSK to influence their business sustainability. 


\subsubsection{Religious Compliance}

The interviews conducted helped clarify the religious activities conducted throughout their business. Among the operations and practises performed are shalat, saying a prayer and other deeds or behaviour of the prophet Muhammad SAW (Sunnah). Evidence of coordination of business ventures with worship to God can also influence honest, trustworthy and responsible behaviour of Muslim women entrepreneurs (Asyraf, 2005; Yaacob \& Azmi, 2012).

Meanwhile, prayer is a practise organised in Islam. The believer who practised prayer to Allah SWT then knows Allah Almighty will fulfil his prayer request as Al-Quran Al-Baqarah, (2:186). Praying is always done by these Muslim women who are small entrepreneurs. They believe it is a practise that can lead to the consolidation of their business so that they are able and remain long because the sustenance gained is a gift from Allah SWT. They believe that entrepreneurial success can occur if they maintain a good relationship with Allah SWT via shalat or saying a prayer request because Allah SWT is the determinant of the success of his people (Abu Bakar and Syarifah, 2005).

Last religion compliance is to practise Sunnah. The women at the PBSK have not missed the practise of Sunnah claimed by Allah SWT and the Messenger of Allah (SAW) who always practise zikir and salawat to the great Prophet Muhammad SAW. They stated that if they had the freedom, they would instead remember, pray and recite surahs. This practise is always done so that they are accustomed to zikir and salawat when they have no customers or have free time. Their leisure time is filled with healthy activities while staying close to Allah SWT because every practise done is a way of connecting people with Allah SWT.

\section{Conclusion and Implications}

Factors affecting the sustainability of Muslim women's entrepreneurship at the PBSK consists of two basic categories such as business type and factors that affect the continuity of business entrepreneurs at the PBSK. An entrepreneur who runs a dry goods business is more sustainable than an entrepreneur who runs other sales items. It happens because dry goods require a less significant bit of capital, and demand for commodities is always there. Among the factors that affect sustainability are three specific factors, namely financial, human and spiritual that affect the survival of Muslim women entrepreneurs throughout their business processes. This can explain why Muslim women who are small entrepreneurs at the PBSK can last a long time in their business even if their business is suffering from loss or profit.

\section{Acknowledgements}

The authors wish to thank and appreciation to the team of the Center for Islamic Development Management Studies (ISDEV) and School of Social Science of Universiti Sains Malaysia, and the Ikatan Ahli Ekonomi Islam team of Indonesia Komisariat Universitas Mercu Buana Jakarta.

\section{References}

Abdullah S., \& M. S. A. (2013). Entrepreneurship and Islam An expository study on characteristics of Muslim entrepreneur. In 5th Islamic Economics System Conference Sustainable Development Through The Islamic Economics System (pp. 467-476). Kuala Lumpur: Faculty Economics and Muamalat, Universiti Sains Islam Malaysia.

Abu Bakar, H., \& Syarifah, M. Y. (2005). Keusahawanan dan Pengurusan Perniagaan Kecil. UUM Press.

Adewale, A. A. (2016). Effect of Demographic Factors on Entrepreneurial Culture: A Study of University Students in Metropolitan Kano. American Journal of Social Sciences and Humanities, 1(1), 10-34.

Agbim, K. C., \& Eluka, J. (2018). Social Network and Family Business Internationalization in South Eastern Nigeria. Journal of Accounting, Business and Finance Research, 3(2), 64-74. https://doi.org/10.20448/2002.32.64.74

Ahmed, U., Khalid, N., Ammar, A., \& Shah, M. H. (2017). Assessing moderation of employee engagement on the relationship between work discretion, job clarity and business performance in the banking sector of Pakistan. Asian Economic and Financial Review, $1197-121$. https://doi.org/10.18488/journal.aefr.2017.712.1197.1210

Ali, A., \& Haseeb, M. (2019). Radio frequency identification (RFID) technology as a strategic tool towards higher performance of supply chain operations in textile and apparel industry of Malaysia. Uncertain Supply Chain Management, 7(2), 215-226. https://doi.org/10.5267/j.uscm.2018.10.004

Ametorwo, A. M. (2016). Managing Work Family Conflict among Female Entrepreneurs in Ghana for Development. International Journal of Economics, Business and Management Studies, 3(1), 21-35. 
Arham, M. (2010). Islamic perspectives on marketing. Journal of Islamic Marketing, 1(2), 149-164. https://doi.org/10.1108/17590831011055888

Asyraf, M. D. (2005). Menjadi Usahawan Muslim Tahan Lasak. Synergy Media.

Bachev, H. (2018). Management and Agrarian Sustainability-Impact of Institutions in Bulgaria. International Journal of Management and Sustainability, 7(2), 113-142. https://doi.org/10.18488/journal.11.2018.72.113.142

Bruderl, J., \& Schussler, R. (1990). Organizational mortality: The liabilities of newness and adolescence. Administrative Science Quarterly, 530-547. https://doi.org/10.2307/2393316

Brush, C. G., De Bruin, A., \& Welter, F. (2009). A gender-aware framework for women's entrepreneurship. International. Journal of Gender and Entrepreneurship, l(1), 8-24. https://doi.org/10.1108/17566260910942318

Bugu, Z. Y., \& Yucheng, H. (2018). An Empirical Analysis of the Factors Affecting the Profitability of China's Agricultural Listed Companies under the Background of Agricultural Modernization. International Journal of Applied Economics, Finance and Accounting, 2(1), 19-26. https://doi.org/10.33094/8.2017.2018.21.19.26

Cole, R. A., \& Wolken, J. D. (1995). Financial services used by small businesses: Evidence from the 1993 National Survey of Small Business Finances. Fed. Res. Bull., 81, 629.

Courtney, K. K., Łukowska, M., \& Williams, E. (2011). European Culture in Diversity. Cambridge Scholars Publishing.

Daud, A. (2004). Faktor-faktor yang Mendorong Usahawan Wanita Berniaga di Pasar Besar Tanah Merah, Kelantan. Universiti Teknologi Malaysia.

De Vita, L., Mari, M., \& Poggesi, S. (2014). Women entrepreneurs in and from developing countries: Evidences from the literature. European Management Journal, 32(3), 451-460. https://doi.org/10.1016/J.EMJ.2013.07.009

De Vries, M. F. R. (1977). The entrepreneurial personality: A person at the crossroads. Journal of Management Studies, 14(1), 34-57. https://doi.org/10.1111/j.1467-6486.1977.tb00616.x

Drucker, P. (2014). Innovation and entrepreneurship (1st ed.). London: Routledge. https://doi.org/10.4324/9781315747453

Essayyad, M., Palamuleni, M., \& Satyal, C. (2018). Remittances and Real Exchange Rates in South Asia: The Case of Nepal. Asian Economic and Financial Review, 8(10), 1226-1238. https://doi.org/10.18488/journal.aefr.2018.810.1226.1238

Gunawardana, H., Tantrigoda, D. A., \& Kumara, U. A. (2018). Integrating Sustainable Land Management for Post-Conflict Economic Recovery. Asian Development Policy Review, 6(3), 129-141. https://doi.org/10.18488/journal.107.2018.63.129.141

Hadi, N. M. H., \& Zainol, F. A. (2015). A Conceptual Model for Entrepreneurial Quality among Students of Higher Education Institutions (HEI) in Malaysia. International Journal of Academic Research in Business and Social Sciences, 5(3), 433. https://doi.org/10.6007/IJARBSS/v5-i3/1537

Idris, N. A. H., \& Shahadan, F. (1991). The role of Muslim women traders in Kelantan. The Muslim Private Sector in Southeast Asia: Islam and the Economic Development of Southeast Asia (p.122).

Iyiola, O. (2014). Supporting Tourism Business in Nigeria via Integrated Marketing. Journal of Tourism Management Research, 1(2), 27-39. https://doi.org/10.18488/journal.31/2014.1.1/31.1.27.93

Jermsittiparsert, K., Sriyakul, T., \& Rodoonsong, S. (2013). Power(lessness) of the State in the Globalization Era: Empirical Proposals on Determination of Domestic Paddy Price in Thailand. Asian Social Science, 9(17), 218-225. https://doi.org/10.5539/ass.v9n17p209

Kamaruddin, R., \& Samsudin, S. (2014). The sustainable livelihoods index: A tool to assess the ability and preparedness of the rural poor in receiving entrepreneurial project. Journal of Social Economic Research, 1(6), 108-117.

Kamyab, S. H. (2014). The Entrepreneurship, Knowledge Spillover and Economic Growth. International Journal of Sustainable Development \& World Policy, 3(2), 45-54.

Kuratko, D. F., \& Hodgetts, R. M. (2001). Entrepreneurship -A Contemporary Approach. Florida: Harcourt College Publishers.

Lee, J. (1996). The motivation of women entrepreneurs in Singapore. Women in Management Review, 11(2), 18-29. 
Lee-Gosselin, H., \& Grisé, J. (1990). Are women owner-managers challenging our definitions of entrepreneurship? An in-depth survey. Journal of Business Ethics, 9(4-5), 423-433. https://doi.org/10.1007/BF00380341

Lindgren, M., \& Packendorff, J. (2003). A project-based view of entrepreneurship: Towards action-orientation, seriality and collectivity. Entrepreneurship: New Movements, 86-102.

Makhbul, Z. M., \& Hasun, F. M. (2010). Entrepreneurial success: An exploratory study among entrepreneurs. International Journal of Business and Management, 6(1), 116-125. https://doi.org/http://doi.org/10.5539/ijbm.v6n1p116

Maldonado-Guzman, G., Pinzon-Castro, S. Y., \& Rodriguez-Gonzalez, R. M. (2018). Brand Management, Competitiveness and Business Performance in Mexican Small Service Businesses. International Journal of Asian Social Science, 8(10), 898-908. https://doi.org/10.18488/journal.1.2018.810.898.908

Mamat, I., Nawang, W. M. Z. W., \& Ramli, N. N. (2009). The Value, Attitude and Practice of Institute of Higher Learning's Senior Officials Towards Graduate Entrepreneur Development Programme. Jurnal Kemanusiaan, $7(2)$.

Megginson, W. L., Byrd, M. J., \& Megginson, L. C. (2000). Small business management: an entrepreneur's guidebook. Irwin/McGraw-Hill.

Merriam, S. B., \& Tisdell, E. J. (2016). Qualitative Research: A Guide to Design and Implementation (4th ed.). San Fransisco: Josey-Bass, Jhon Willey \& Sons, Inc.

Ming-Yen, T. W., \& Siong-Choy, C. (2007). Theorising a framework of factors influencing performance of women entrepreneurs in Malaysia. Journal of Asia Entrepreneurship and Sustainability, 3(2), 1.

Nor Aini, I., \& Faridah, S. (1991). The Role of Women Muslim Traders in Kelantan. In The Muslim Private Sector in Southeast Asia (pp. 122-151).

Normaisarah, M. Z. (2014). Faktor-faktor Yang Mempengaruhi Kelestarian Usahawan Kecil Wanita Muslim Di Pasar Besar Siti Khadijah (PBSK), Kota Bharu, Kelantan. Universiti Sains Malaysia.

Nugroho, A., \& Sihite, J. (2015). Does The Social Network Relate With The Entrepreneurship? An Empirical Content Analysis. Jurnal Manajemen, 19(2), 205-218. https://doi.org/10.24912/jm.v19i2.124

Obi, M. N., \& Okekeokosisi, J. (2018). Extent of Implementation of National Entrepreneurship Curriculum in Tertiary Institutions as Perceived by Educators. American Journal of Education and Learning, 3(2), 108-115. https://doi.org/10.20448/804.3.2.108.115

Okafor, C., \& Shaibu, I. (2016). Modelling Economic Growth Function in Nigeria: An ARDL Approach. Asian Journal of Economics and Empirical Research, 3(1), 84-93. https://doi.org/10.20448/journal.501/2016.3.1/501.1.84.93

Omar, O. (2010). Siri Syarahan Umum: Pengurusan Projek dan Kelestarian Titik Pertemuan. Penerbit USM.

Omar, S. S. (2015). The entrepreneurial network of Muslim women entrepreneurs: The study of multiple-cases of small businesses in the southern region of Malaysia. International Journal of Economics and Financial Issues, 5(1S), 106-115.

Orhan, M., \& Scott, D. (2001). Why women enter into entrepreneurship: an explanatory model. Women in Management Review, 16(5), 232-247. https://doi.org/10.1108/09649420110395719

Pihie Lope, Z. A., \& Elias, H. (2004). Keupayaan Usahawan Bumiputera Melaksanakan Kemahiran Keusahawanan: Satu Kajian Kes. Pertanika J. Soc. Sci. \& Hum., 12(1), 61-70.

Ramadani, V., Dana, L.-P., Ratten, V., \& Tahiri, S. (2015). The context of Islamic entrepreneurship and business: Concept, principles and perspectives. International Journal of Business and Globalisation, 15(3), 244-261. https://doi.org/10.1504/IJBG.2015.071906

Reda, A. (2013). Trading with Allah: an examination of Islamic scripture in relation to markets. Journal of Markets \& Morality, 16(2), 441-462.

Rekarti, E., \& Doktoralina, C. M. (2017). Improving Business Performance: A Proposed Model for SMEs. European Research Studies Journal, 20(3), 613-623.

Rekarti, E., Doktoralina, C. M., \& Srianah. (2017). Building Customer's Buying Interests To Traditional Nuance Restaurants: A Model Of Proposed Study. In The 1st International Conference on Economic, Business and 
Accounting (ICEBA) (p. 102).

Scarborough, N. M. (2016). Essentials of entrepreneurship and small business management. Pearson.

Segun, O. P. (2016). Investment in Cocoa Planting and Rehabilitation by Cocoa Farmers in Nigeria. Asian Journal of Economics and Empirical Research, 3(1), 17-24. https://doi.org/10.20448/journal.501/2016.3.1/501.1.17.24

Setiyawati, H., Iskandar, D., \& Basar, Y. S. (2018). The Quality of Financial Reporting through Increasing the Competence of Internal Accountants and Accrual Basis. International Journal of Economics, Business and Management Studies, 5(1), 31-40. https://doi.org/10.20448/802.51.31.39

Shahbaz, M., Hye, Q. M. A., Tiwari, A. K., \& Leitão, N. C. (2013). Economic growth, energy consumption, financial development, international trade and $\mathrm{CO} 2$ emissions in Indonesia. Renewable and Sustainable Energy Reviews, 25, 109-121. https://doi.org/10.1016/j.rser.2013.04.009

Shannahan, D. (2016). Textual Queerings: Contesting Islam as Heteronormative Inheritance. In The Ashgate Research Companion to Contemporary Religion and Sexuality (pp. 123-138). Routledge.

Singh, S., Simpson, R., Mordi, C., \& Okafor, C. (2011). Motivation to become an entrepreneur: a study of Nigerian women's decisions. African Journal of Economic and Management Studies, 2(2), 202-219. https://doi.org/10.1108/20400701111165641

Sitterly, C. (1994). The female entrepreneur: Overcoming challenges in the business world. Crisp Publications.

Tlaiss, H. A. (2015). How Islamic Business Ethics Impact Women Entrepreneurs: Insights from Four Arab Middle Eastern Countries. Journal of Business Ethics, 129(4), 859-877. https://doi.org/10.1007/s10551-014-2138-3

Udanoh, M. U., \& Zouria, A. (2018). Using Gender Inequality to Predict the Rate of African Women Entrepreneurship. International Journal of Emerging Trends in Social Sciences, 3(1), 17-28. https://doi.org/10.20448/2001.31.17.28

Wan Hussin, W. S. (2003). Ciri-Ciri Usahawan Berjaya dari Perspektif al-Qur'an. Jurnal Usuluddin, (18), 81-110.

Wiklund, J., \& Shepherd, D. (2005). Entrepreneurial orientation and small business performance: a configurational approach. Journal of Business Venturing, 20(1), 71-91. https://doi.org/10.1016/j.jbusvent.2004.01.001

Wye, C. K., \& Lim, Y. M. (2014). Analyzing Skill Profile Among Business Graduates: Is it Generic or Specific?. International Journal of Business, Economics and Management, 1(5), 57-71.

Yaacob, Y., \& Azmi, I. A. G. (2012). Entrepreneurs' personality from Islamic perspective: A study of successful Muslim entrepreneurs in Malaysia. International Proceedings of Economics Development and Research, 46(16), 86-90.

Zahra, S. A., \& George, G. (2002). Absorptive capacity: A review, reconceptualization, and extension. Academy of Management Review, 27(2), 185-203. https://doi.org/10.5465/amr.2002.6587995

Zulkifli, C., Omar, C., Siti, A., \& Saripuddin, S. (2015). Concept of business ethics in Islam: Approach to the entrepreneur. Journal of Asian Business Strategy, 5(1), 13-18. 